\title{
PONTICULI IN ATLAS VERTEBRAE AND ITS CLINICAL ASPECT
}

\section{Berjina Farooq Naqshi ${ }^{1}$, Adil Bashir Shah ${ }^{* 2}$, Sangeeta Gupta ${ }^{3}$.}

${ }^{1}$ Demonstrator, Department of Anatomy, Government Medical College, Srinagar, Kashmir, India.

${ }^{* 2}$ Registrar, Department of Orthopaedics, Government Medical College, Srinagar, Kashmir, India.

${ }^{3}$ Professor, Department of Anatomy, Government Medical College, Jammu, India.

\section{ABSTRACT}

Background: Atlas, the first cervical vertebra, has an oblique ligament which bridges the groove for vertebral artery. This ligament may ossify sometimes converting groove into foramen. These foramina are called as ponticulus posterior or arcuate foramen of the atlas. The ponticuli can distort vertebral artery. They have tendency to cause vertebra basic insufficiency. During any manipulation of cervical spine, these variations of atlas should be kept in mind.

Objectives: To study the presence of ponticuli, their other features like whether complete or incomplete, unilateral or bilateral, sidedness- right or left.

Material and Methods: A total of 50 fully dried adult human atlas were collected from the Department of Anatomy, Government Medical College, Jammu and from the students of the first year MBBS, Government Medical College, Jammu. Bones were intact and free from osteophytes. The superior surface of posterior arch was observed carefully in each atlas for presence of ponticulus.

Results: In the present study, 50 human atlas vertebrae were observed out of which 4 atlas (8\%) had ponticuli. It was incomplete in 2 vertebrae (4\%) and was complete in 2 atlas vertebrae (4\%). It was unilateral in 3 atlas vertebrae (6\%) and bilateral in 1 atlas vertebra (2\%). 2 ponticuli were on the right side, 1 on left side and 2 were found on both sides. All were ponticuli posterior except one which was lateral ponticulus.

Conclusion: The presence of ponticuli can cause cervical pain and pressurize vertebral artery leading to cerebrovascular accidents. Detailed knowledge about the variations in the cervical region is very helpful to neurosurgeons, orthopaedicians and otolaryngologists to avoid any mishap. Spinal surgeons must be fully aware about these ponticulus to prevent any complications during surgeries.

KEYWORDS: Ponticulus, Arcuate foramen, Atlas vertebra, Neurosurgeons.

Address for Correspondence: Dr. Adil Bashir Shah, Registrar, Department of Orthopaedics, Government Medical College, Srinagar, Kashmir, India. E-Mail: adilshah111@gmail.com.

Access this Article online

Quick Response code

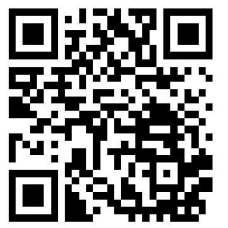

DOI: $10.16965 /$ ijar.2017.497

Journal Information

International Journal of Anatomy and Research

ICV for 2016
90.30 $\begin{gathered}\text { ISSN (E) 2321-4287 | ISSN (P) 2321-8967 } \\ \text { https://www.ijmhr.org/ijar.htm } \\ \text { DOI-Prefix: https://dx.doi.org/10.16965/ijar }\end{gathered}$

\section{Article Information}

Received: 06 Nov 2017

Peer Review: 07 Nov 2017

Revised: None
Accepted: 02 Jan 2018

Published (O): 05 Feb 2018

Published (P): 05 Feb 2018

\section{INTRODUCTION}

First cervical vertebra, atlas is an atypical vertebra. According to Greek mythology, its name has been derived after "ATLAS" who supported earth on shoulders [1]. Atlas is devoid of body and spine and is ring shaped [2]. Globe of head is being stabilised by atlas. Atlas has two lateral masses being connected by anterior and posterior arch. The posterior arch superiorly has a groove present behind the lateral mass of atlas which is being traversed by the vertebral artery ( $3^{\text {rd }}$ part), plexus of veins and $\mathrm{C} 1$ nerve (dorsal ramus) [3]. There is an oblique ligament which bridges the groove for vertebral artery. This ligament may ossify sometimes converting groove into foramen [4]. These foramina are 
called as ponticulus posterior or arcuate foramen of the atlas [5]. Occassionally a bony bridge can extend from posterior root of transverse process to the lateral masses forming a foramen called ponticulus lateralis through which vertebral artery passes [6]. The posterior ponticuli and lateral ponticuli can sometimes be present together and form posterolateral ponticuli. These ponticuli can distort vertebral artery [7]. They have tendency to cause vertebra basic insufficiency $[8,9]$. During any manipulation of cervical spine, these variations of atlas should be kept in mind [10].

\section{OBJECTIVES}

1. To study incidence of ponticuli in atlas vertebrae.

2. To study if ponticuli in atlas are unilateral or bilateral.

3. To find the presence of complete or incomplete ponticuli in atlas.

4. To study if ponticuli are on right or left side of atlas vertebra.

\section{MATERIALS AND METHODS}

The present study was done on 50 fully dried adult human atlas, which were collected from the Department of Anatomy, Government Medical College, Jammu and from the students of the first year MBBS, Government Medical College, Jammu. Bones were intact and free from osteophytes. The superior surface of posterior arch was observed carefully in each atlas for presence of ponticulus.

\section{RESULTS}

In the present study, 50 human atlas vertebrae were observed out of which $4(8 \%)$ atlas had ponticuli. Ponticulus was incomplete in 2 (4\%) vertebrae and was complete in $2(4 \%)$ atlas vertebrae. It was unilateral in $6 \%$ and bilateral in $2 \%$. Out of 5 ponticuli, 2 ponticuli were on the right side, 1 on left side and 2 were found on both the sides. All were ponticuli posterior except one which was lateral ponticulus. In total there were 5 ponticuli in 4 atlas vertebrae. (Fig:1 to 4, Table:1-7)

Table 1: Incidence of ponticuli in atlas.

\begin{tabular}{|c|c|}
\hline Total number & $\begin{array}{c}\text { Percentage of } \\
\text { ponticuli }\end{array}$ \\
\hline 50 & $8 \%$ \\
\hline
\end{tabular}

Table 2: Percentage of complete and incomplete ponticuli.

\begin{tabular}{|c|c|c|}
\hline $\begin{array}{c}\text { Total no. of atlas } \\
\text { having ponticuli }\end{array}$ & $\begin{array}{c}\text { Percentage of } \\
\text { incomplete ponticuli }\end{array}$ & $\begin{array}{c}\text { Percentage of } \\
\text { complete ponticuli }\end{array}$ \\
\hline $4(8 \%)$ & 4 & 4 \\
\hline
\end{tabular}

Table 3: Percentage of unilateral and bilateral ponticuli.

\begin{tabular}{|c|c|c|}
\hline $\begin{array}{c}\text { Total number of atlas } \\
\text { having ponticuli }\end{array}$ & Unilateral \% & Bilateral \% \\
\hline 4 & 6 & 2 \\
\hline
\end{tabular}

Table 4: Percentage of right/left side of the ponticuli.

\begin{tabular}{|c|c|c|c|}
\hline $\begin{array}{c}\text { Total number of atlas } \\
\text { having ponticuli }\end{array}$ & Right & Left & Bilateral \\
\hline 4 & 2 & 1 & 1 \\
\hline
\end{tabular}

Table 5: Percentage of incomplete ring.

\begin{tabular}{|c|c|c|c|}
\hline $\begin{array}{c}\text { Total number of } \\
\text { ponticuli }\end{array}$ & Right & Left & Bilateral \\
\hline 2 & 1 & 1 & 0 \\
\hline
\end{tabular}

Table 6: Percentage of complete ring.

\begin{tabular}{|c|c|c|c|}
\hline $\begin{array}{c}\text { Total number } \\
\text { of ponticuli }\end{array}$ & Right & Left & Bilateral \\
\hline 3 & 1 & 0 & $\begin{array}{c}1 \\
\text { (i.e 2 ponticuli) }\end{array}$ \\
\hline
\end{tabular}

Fig. 1: Bilateral complete ponticulus posterior

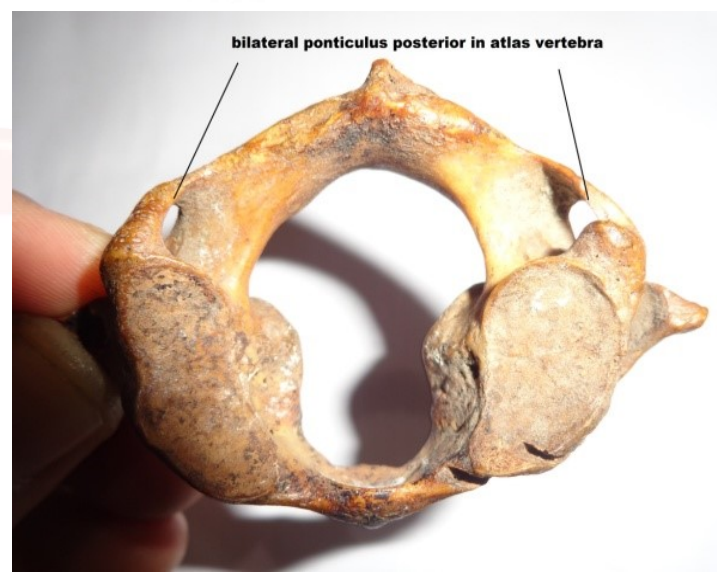

Fig. 2: Incomplete ponticulus posterior

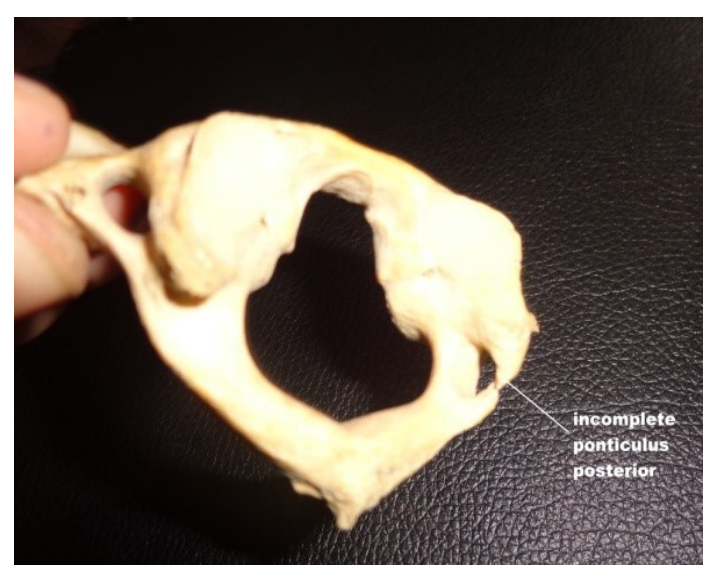


Fig. 3: unilateral ponticulus lateralis

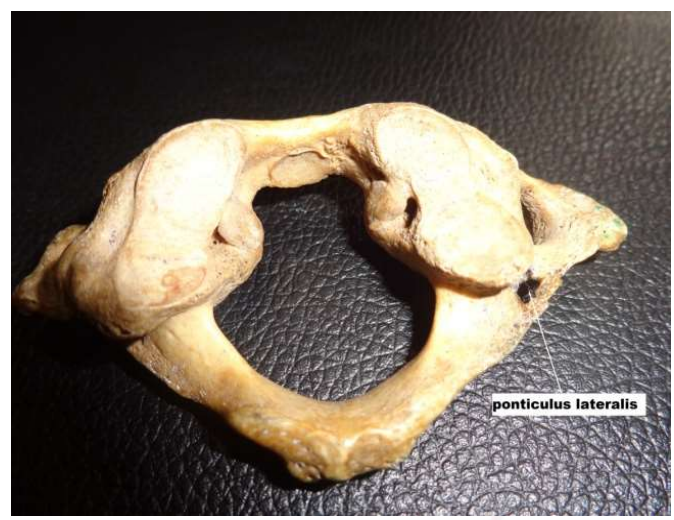

Fig. 4: Unilateral incomplete ponticulus posterior

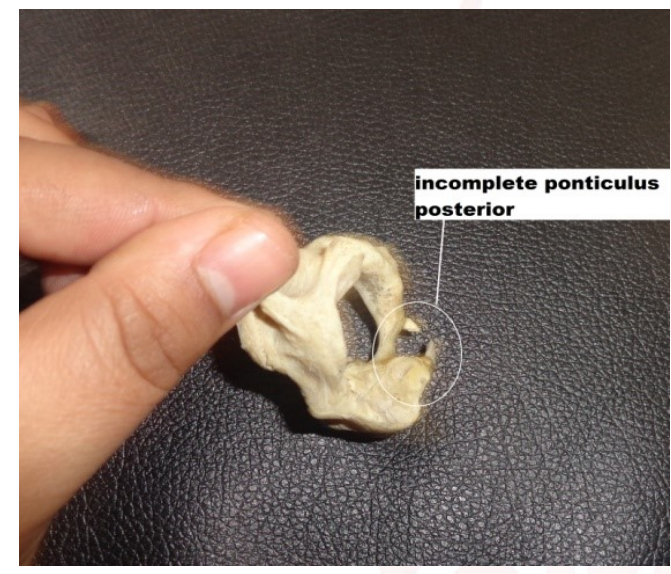

DISCUSSION

Detailed knowledge about the anatomy around the cervical region becomes necessary because various congenital, neoplastic and traumatic conditions continue to progress [11]. The mechanism behind the ossification of ligament can be due to age. It can be due to external mechanical forces like heavy loads. Pulsations of the vertebral artery can also induce the ossification of ligament. Some suggest that they might be remnants of proatlas $[5,8,12]$. The incomplete bony ponticuli was hypothesized a precursor of the complete bony ponticuli [13].

Hasan et al [12] classified arcuate foramen into 6 groups:

I - impression of vertebral artery.

II - Distinct groove.

III- Incomplete posterior ponticulus.

IV-Complete posterior ponticulus.

$\mathrm{V}$ - Lateral ponticulus extended from lateral mass to transverse process.

$\mathrm{VI-}$ posterolateal ponticulus made by combination of complete posterior and lateral ponticulus [12].
Ponticuli of atlas is a clinical and anatomical variant [14]. Vertebral artery tethering can occur due to ponticulus leading to its dissection due to trauma by the various head movements [15]. Radiography of cervical spine is a valuable tool if there is suspicion of arcuate foramen especially if the patient complains of headache, temporal region pain, retro orbital pain, vertigo, periodic photophobia, pain in shoulders etc [16].

Table 7: Comparison of results of present study with previous studies.

\begin{tabular}{|c|c|c|c|c|c|}
\hline Study & Material & Incomplete\% & Complete \% & $\begin{array}{c}\text { Unilateral/ } \\
\text { Bilateral }\end{array}$ & $\mathrm{R} / \mathrm{L}$ \\
\hline Hasan et al,2001 [12] & osteological & $6.57 \& 2$ & 3.4 & - & - \\
\hline Dahiphale et al,2009 [17] & osteological & 18 & 2 & - & - \\
\hline Venkatachalam,2015 [18] & osteological & 8 & 4 & Unilateral & $\mathrm{L}$ \\
\hline Present study, 2017 & osteological & 4 & 4 & Unilateral & $\mathrm{R}$ \\
\hline
\end{tabular}

\section{CONCLUSION}

The presence of ponticulus was seen in $8 \%$ of atlas. Complete ponticulus was seen in $4 \%$ of vertebrae and incomplete ponticulus were observed in $4 \%$ of vertebrae. Their presence can cause cervical pain and pressurize vertebral artery leading to cerebrovascular accidents. Detailed knowledge about the variations in the cervical region is very helpful to neurosurgeons, orthopaedicians and otolaryngologists to avoid any mishap. Spinal surgeons must be fully aware about these ponticulus to prevent any complications during surgeries.

\section{ACKNOWLEDGEMENTS}

The author is indebted to the Head of Departmnt, Jammu for providing the bones for the study.

\section{Conflicts of Interests: None}

\section{REFERENCES}

[1]. Keith L Moore. The back. Satterfield TS. Clinically Oriented Anatomy. $3^{\text {rd }}$ ed: Baltimore, Williams and Wilkins. 1992; p.331.

[2]. Last RJ. In Anatomy Regional and Applied. $11^{\text {th }}$ ed: J and A Churchill Ltd. London. 2006; p.443.

[3]. Standring S. Gray's Anatomy. The anatomical basis of clinical practice. $40^{\text {th }}$ ed: London, Churchill Livingstone. 2008; p.719.

[4]. Richard LM Newell. "The Back" in Gray's Anatomy: The Anatomical Basis of Clinical Practices, S. Standring, H. Ellis, J.C. Healy, D. Jhonson and A. Williams, Eds; Churchill Livingstone, New York, NY, USA, $40^{\text {th }}$ ed:2008, p.720. 
[5]. Tubbs RS, Johnson PC, Shoja MM, Loukas M, Oakes WJ. Foramen arcuale: Anatomical study and review of the literature. J Neurosurg Spine. 2007;6(1):3134.

[6]. Taitz $\mathrm{C}$ and Nathan H. Some observations on the posterior and lateral bridge of the atlas. Acta Anatomica. 1986; 127(3):212-217.

[7]. Mehlic T and Farhat SM. Vertebral artery injury from chiropractic manipulation of the neck. Surgical Neurology. 1974;2:125-129.

[8]. Sylvia S, Kulkarni S, Hatti A. Bilateral retro articular ring in atlas vertebra- A case report. Anatomica Karnataka. 2011;5(1):81-86.

[9]. Karau PB, Ogeng'o JA, Hassanali J, Odula PO. Morphometry and variations of bony ponticles of the atlas vertebra (C1) in Kenyans. Int J of Morphology. 2010;28(4): 1019-1024.

[10]. Mitchel J. The incidence of the lateral bridge of the atlas vertebra. J of Anat. 1998b;193:283-285.

[11]. Akhtar MJ, Fatima N, Ritu, Kumar V. A morphological study of ponticuli of the human atlas vertebrae and its clinical significance. International Journal of Anatomy and Research. 2015;3(4):1597-1602.

[12]. Hasan M, Sanjeev S, Shakil MS, Singh D. Posterolateral tunnels and ponticuli in human atlas vertebra. 2001;199:339-343.
[13]. Paraskevas G, Papaziogas B, Tsonidis C, Kapetanos G. Gross morphology of the bridges over the vertebral artery groove on the atlas. Surg Radiol Anat. 2005;27(2):129-136.

[14]. Malukar O, Prajapati VP, Nagar SK. Ponticulus posticus of the atlas vertebra. National Journal of Medical Research. 2011;1(2):51-53.

[15]. Cushing KE, Ramesh V, Gardner Medwin D, Todd NV, Gholkar A, Baxter P, Griffiths PD. Tethering of the vertebral artery in the congenital arcuate foramen of the atlas vertebra: a possible cause of vertebral artery dissection in children. Dev Med Child Neurol. 2001;43(7):491-496.

[16]. Cakmak O, Gurdal E, Ekinci G, Yildiz E, Cavdar S. Arcuate foramen and its clinical significance. Saudi Med J. 2005;26:1409-1413

[17]. Dahiphale VP and Bahetee BH. The retro articular vertebral artery ring of the atlas and its significance. Journal of Anatomical Society of India. 2009;58(2):149-151.

[18]. Venkatachalam N. Ponticuli in human atlas vertebrae and its significance. International Journal of Health Sciences and Research. 2015;5(6):246-250.

$$
\begin{aligned}
& \text { How to cite this article: } \\
& \text { Berjina Farooq Naqshi, Adil Bashir Shah, Sangeeta Gupta. } \\
& \text { PONTICULI IN ATLAS VERTEBRAE AND ITS CLINICAL ASPECT. Int } \\
& \text { J Anat Res 2018;6(1.2):4880-4883. DOI: 10.16965/ijar.2017.497 }
\end{aligned}
$$

